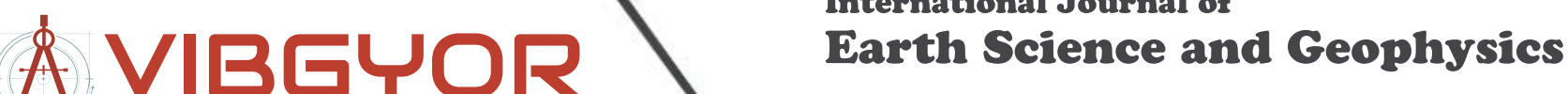

ISSN: 2631-5033

\title{
Inclusion of Faults in 3-D Numerical Simulation of Carbon Dioxide Injection into the South Georgia Rift Basin, South Carolina
}

\author{
Duke Brantley ${ }^{*}$, Mike WaddelI', John Shafer ${ }^{2}$ and Venkat Lakshmi ${ }^{3}$ \\ ${ }^{1}$ Earth Sciences and Resources Institute, University of South Carolina, Columbia, USA \\ ${ }^{2}$ Sundance Environmental and Energy Specialists, Ltd. 321 Lake Front Dr., Columbia, USA \\ ${ }^{3}$ Department of Earth and Ocean Sciences, University of South Carolina, 701 Sumter St., Columbia, USA
}

\begin{abstract}
This paper reviews the effects of faulting on the numerical simulation of $\mathrm{CO}_{2}$ injection into the South Georgia Rift (SGR) basin. The focus of this research is to use a 3-D geologic model that includes structure and faulting to better analyze the impact of these features on the ultimate fate of injected $\mathrm{CO}_{2}$. Newly acquired basin data has revealed that the SGR basin is a highly fractured and faulted basin; therefore, the effect of the faulting on $\mathrm{CO}$ migration must be considered when determining the efficacy of geologic storage of $\mathrm{CO}_{2}$ in this basin. Petre ${ }^{\mathrm{TM}}$ was used to construct the 3-D geologic model and this model was imported into $\mathrm{CMG}^{2}-\mathrm{GEM}^{\mathrm{TM}}$ compositional reservoir simulator for $\mathrm{CO}_{2}$ injection simulations. Total simulation time was 100 years during which a total of 30 million tons of $\mathrm{CO}_{2}$ were injected at a rate of 1 million tons per year for 30 years followed by a 70 year shut-in period. Multiple experiments were run to find the effects of fault permeability on the resultant fate of the injected $\mathrm{CO}_{2}$. Fault permeabilities reviewed in this paper are: $0 \mathrm{mD}$ representing a sealing fault, $1 \mathrm{mD}$ representing a low permeability fault, and $100 \mathrm{mD}$ representing a conduit fault. The results illustrate that with a permeability of $1 \mathrm{mD}$, significant leakage of $\mathrm{CO}_{2}$ occurs up the faults. This is evidence that fault analysis is a critical factor in injection simulation modeling and that even low permeability faults make the geology potentially unsuitable for long term geologic storage of $\mathrm{CO}_{2}$.
\end{abstract}

\section{Keywords}

Injection Simulation, $\mathrm{CO}_{2}$ Sequestration, 3-D Numerical Simulation, Fault Analysis, Geologic Storage, CMG-GEM

\section{Background}

This research was motivated by a grant from the US Department of Energy's National Energy and Technology Laboratory (US DOENETL) for the characterization of the South Georgia Rift (SGR) basin to determine the feasibility and efficacy of long term geologic storage of supercritical carbon dioxide $\left(\mathrm{CO}_{2}\right)$. Geologic storage of $\mathrm{CO}_{2}$, a greenhouse gas, is a means of reducing anthropogenic contributions to the atmospheric concentrations of $\mathrm{CO}_{2}$ [1-6]. Reducing atmospheric $\mathrm{CO}_{2}$ is important because of the evidence that links increased atmospheric $\mathrm{CO}_{2}$ concentrations with increased atmospheric temperature. In a global effort to mitigate the anthropogenic release of $\mathrm{CO}_{2}$ into the atmosphere, carbon capture, utilization and storage (CCUS) technology has become a major area of research in the global warming arena [7-13].

Other basins along the Eastern North American Rift System (ENARS) (Figure 1) have been studied extensively but due to lack of petroleum industry exploration, very few legacy data are available about the geology of the SGR basin. The SGR basin is the southernmost rift basin along the ENARS and as indicated by the Norris Lightest \# 1 well (N.L. \# 1) is comprised of Triassic and Early Jurassic continent derived fluvial and lacustrine sandstone, siltstone and mudstones intercalated with layers of basalt and/or diabase $[7,14,15]$. The N.L. \# 1 is a petroleum exploration well that was drilled to a depth of 4,115 $\mathrm{m}$ and is the only well that goes through the $3000+\mathrm{m}$ of the Jurassic/ Triassic J/T $\mathrm{T}_{\mathrm{r}}$ section of the basin [16]. The University of South Carolina has led a SGR basin characterization study to determine the feasibility of long-term geologic storage of $\mathrm{CO}_{2}$. This project was divided into three stages. The first stage evaluated of all existing (legacy) data pertaining to the SGR basin using well logs and statistics $[7,17]$. During the second stage, approximately 386 kilometers $(\mathrm{km})$ [ 240 miles (mil)] of new seismic data were acquired and evaluated for optimum location of a deep characterization borehole. During the third and final stage a characterization borehole (i.e., Rizer \# 1) was drilled. Petrophysical and geochemical testing within the borehole were performed and core and cuttings samples were examined for petrology.

*Corresponding author: Duke Brantley, Earth Sciences and Resources Institute, University of South Carolina, 1233 Washington Street Suite 300, Columbia, SC 29208, USA, E-mail: brantley@esri.sc.edu

Received: August 05, 2015: Accepted: January 18, 2016: Published: January 22, 2016

Copyright: $\odot 2016$ Brantley D, et al. This is an open-access article distributed under the terms of the Creative Commons Attribution License, which permits unrestricted use, distribution, and reproduction in any medium, provided the original author and source are credited. 


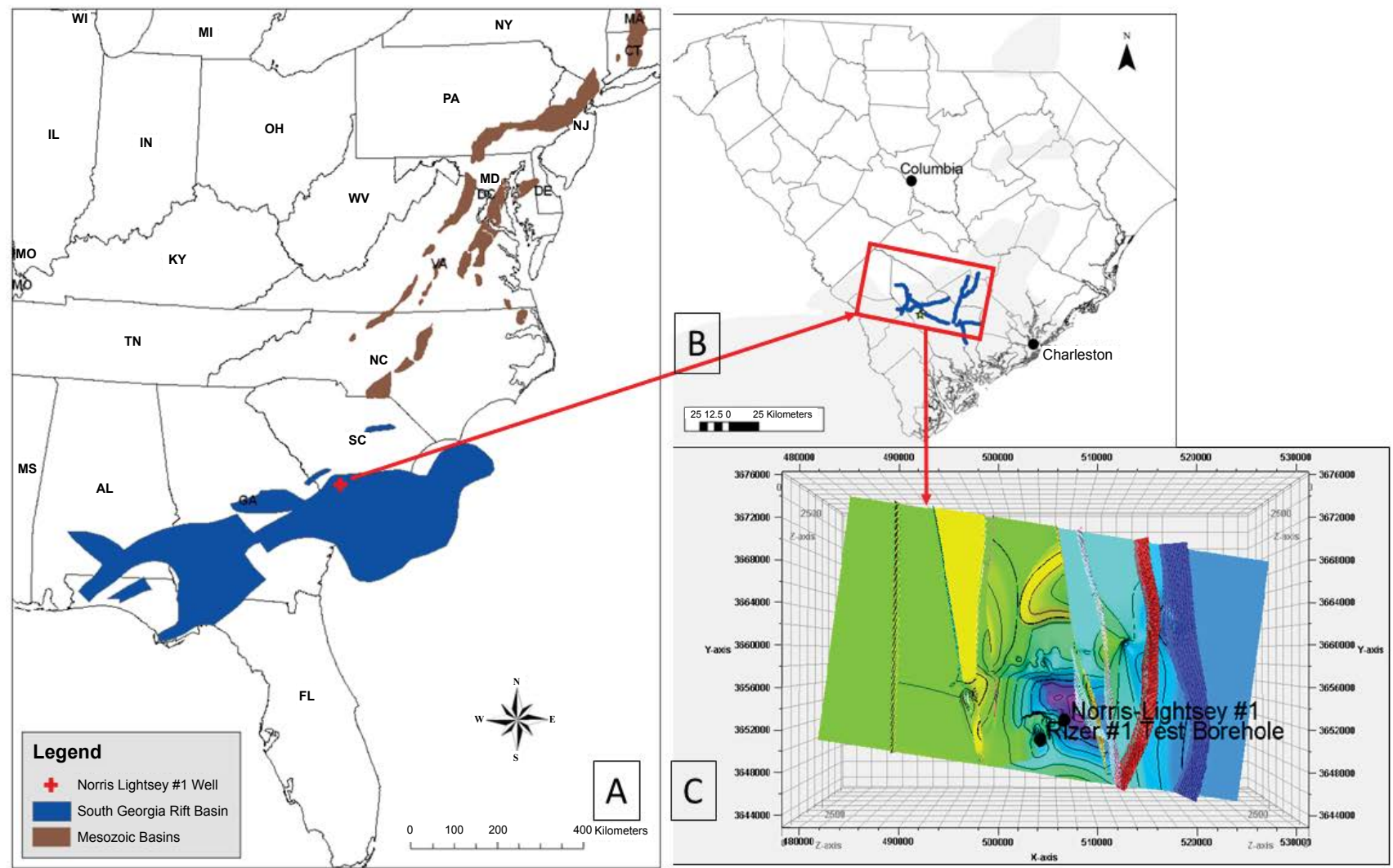

Figure 1: Location maps showing the study area and the injection simulation domain boundaries. Map (A) shows the South Georgia Rift basin in relation to the ENARS. Map (B) shows the location of the study area within the SGR basin and Map (C) is the top surface, Diabase C, of the 3-D geologic map produced using Petrel $^{\mathrm{TM}}$. Color variation indicates the surface depth and various faults.

The SGR basin is of particular importance for several reasons: 1) The large areal extent of the SGR basin (Figure 1) could prove to have large $\mathrm{CO}_{2}$ storage capacity, 2) The SGR basin is classified by the US DOE-NETL as a "high potential" basin that represents a significant storage opportunity in a region with adequate seals that could be commercially developed in the future [18] and 3) The proximity of the SGR basin to major sources of $\mathrm{CO}_{2}$ in the southeastern United States. The SGR basin provides a unique opportunity for geologic carbon storage because the basin is not perforated with wells and boreholes, which could be potential leakage pathways that must be considered for long-term geologic storage of $\mathrm{CO}_{2}$.

Phase One of $\mathrm{CO}_{2}$ injection simulation into the SGR basin was a preliminary assessment using a simplified geocellular model and prespecified basin parameters- porosity and permeability [7]. This current paper focuses on the second phase of $\mathrm{CO}_{2}$ injection simulation into the SGR basin using newly acquired data and a 3-dimensional (3-D) geologic model built in Schlumberger's Petrel ${ }^{\mathrm{TM}}$. Petrel ${ }^{\mathrm{TM}}$ is a stateof-the-art industry grade reservoir engineering software platform that enables collaboration of scientists and engineers to develop and contribute to a single dynamic earth model [19]. The focus of the second phase of the injection simulation is to use the model to study the impact of the geologic structure, particularly faults, on the fate of the buoyancy driven $\mathrm{CO}_{2}$ plume. The SGR basin characterization study has revealed that the basin is highly fractured and faulted; therefore, the effect of the faulting on $\mathrm{CO}_{2}$ migration must be considered when determining the efficacy of geologic storage of $\mathrm{CO}_{2}$.

\section{Research Objectives}

The goal of this research is to numerically simulate $\mathrm{CO}_{2}$ injection into the $\mathrm{J} / \mathrm{T}_{\mathrm{r}}$ material within the South Georgia Rift basin. Using newly acquired seismic and borehole geophysics data, phase two of the injection simulation modeling created a more realistic $\mathrm{CO}_{2}$ injection simulation model for the SGR basin as compared to our previous study [7]. For phase two, an entirely new domain (compared to that in the previous study of [7]) was created (Figure 1) using: 1) The 3-D grid from Petrel ${ }^{\mathrm{TM}}$ that includes interpreted basin structure and 2) Parameterization using SGR basin material data derived from Weatherford Laboratories' petrophysical analyses and the newly acquired Rizer \# 1 characterization borehole geophysical logs. Rizer \# 1 is a characterization borehole drilled to validate the newly acquired seismic data as well as to correlate to horizons evident in the N.L. \# 1 well. The 3-D geologic model created in Petrel $^{\mathrm{TM}}$ provides a refined stratigraphic, volumetric and structural domain that includes faults. This geologic model along with the empirically derived material data provided by Weatherford Laboratories, allowed us to create an injection simulation model realistic to SGR basin conditions than the phase one modeling effort, which was mostly parameterized using basin data based on literature and the N.L. \# 1 well log. Research done by [20] suggests faults, fractures and deteriorated abandoned drill holes or wells comprise primary risk factors for leakage in engineered $\mathrm{CO}_{2}$ injection systems. Corroborating this finding [21], concluded that risk assessments of potential sequestration site leakage should consider faults and fracture zones to evaluate the potential for premature failure of a designed system. Faults can either serve as high permeability by-pass conduits that allow $\mathrm{CO}_{2}$ to escape out of the target reservoir or they can act as low permeability seals that can aid in the compartmentalization of $\mathrm{CO}_{2}$ in the target reservoir. In this work, we estimated a permeability range within the faults based on the Rizer \# 1 borehole geophysical logs and used this range to investigate the impact of faults on the flow of supercritical $\mathrm{CO}_{2}$ into the fractured and faulted diabase injection zone. The goal of these simulations were to: 1) create a new dynamic model of the SGR basin for $\mathrm{CO}_{2}$ injection simulation, 2) analyze the effects of fractures and faulting in the injection reservoir and seal geology, and 3) test the feasibility of the SGR basin for the long term storage of 30 million tons of supercritical $\mathrm{CO}_{2}$. 
The long term fate of injected $\mathrm{CO}_{2}$ for geologic storage is divided into four different storage modes: 1) Free gas, 2) Trapped gas, 3) Dissolved in the formation brine and 4) Gas sequestered as solid minerals or mineralization trapping. Modes 1,2 and 3 can be simulated with multiphase flow simulators such as TOUGH2-ECO2N [7,22-25] and CMG-GEM [26,27]. However, the mineralization trapping can only be simulated using a reactive transport model $[28,29]$. In this study, we focused on the first, second and third modes using the multiphase simulator CMG-GEM. GEM is the Computer Modeling Group's (CMG) Generalized equation-of-state Model (GEM) compositional simulator which includes options such as $\mathrm{CO}_{2}$ miscible gases, volatile oil, gas condensate, horizontal wells, well management, complex phase behavior among others (http://www. cmgl.ca/software/gem2014, GEM2014.10, 2014).

\section{South Georgia Rift Geology - Newly Acquired Data}

Prior to the South Georgia Rift basin characterization study previously described in the background section of this paper, very little geologic investigation had been done in the SGR basin. This is mainly due to: 1) Lack of interest from the petroleum industry and 2) Depth of the basin being below geologic mapping efforts. However, the recent characterization study catalogued numerous geological, geophysical and petrophysical research [7,14-16,30-38]. During the second phase of the characterization study, approximately $386 \mathrm{~km}$ ( $\sim 240 \mathrm{mi}$ ) of seismic data were collected, processed and interpreted. During the third phase of the project, the characterization borehole Rizer \# 1 was drilled to a depth of approximately 1,889 m ( 6,200 $\mathrm{ft}$.) Cores from this borehole were sent to Weatherford' Laboratories for petrophysical analyses. The results from the Weatherford Laboratories analyses indicate that the SGR basin was once buried up to $5 \mathrm{~km}(3.1 \mathrm{mi})$ deeper than previously believed. At that depth, the target reservoir (Diabase C) would have been buried up 7,750 m $(25,427 \mathrm{ft}$.) deep [36]. Due to the depth of the burial of the sandstone, there was significantly more compression of the material than was previously thought before the characterization study. For this reason, the postulated porosity and permeability $(6 \%$ and $10-100 \mathrm{mD}$ respectively) [7] data used in phase one of the injection simulation modeling were significantly over estimated. Newly analyzed data suggest average ambient porosities for rotary and conventional core samples are $3.4 \%$ and $3.1 \%$, respectively, and average permeability of rotary air and conventional core samples are between 0.065 millidarcy $(\mathrm{mD})$ and $0.0049 \mathrm{mD}$, respectively. These values of porosity and permeability values are markedly different than this used in the phase one study.

Using the newly acquired petrophysical data, along with the newly acquired seismic data, a 3-D geologic model of the study was created using Petrel $^{\mathrm{TM}}$. The results of the SGR basin characterization study have drastically changed what was once thought about the SGR basin, in particular, about the efficacy of using the Triassic sandstone horizons for permanent geologic storage of supercritical $\mathrm{CO}_{2}$.

\section{Modeling}

The complexity of the SGR basin structure presented a challenge in developing the 3-D geologic model in Petrel ${ }^{\mathrm{TM}}$. The only units that could be mapped between the Rizer \# 1 borehole and the N.L. \# 1 borehole are the diabase intrusive units. The N.L. \# 1 boring log indicates sequences of sandstone, diabase, and shale and was used to correlate with the newly acquired seismic and borehole data to help produce the 3-D geologic model. The complexity of the structure made correlation between sandstone units almost impossible. The following horizons were mapped: base of the Coastal Plain, the top

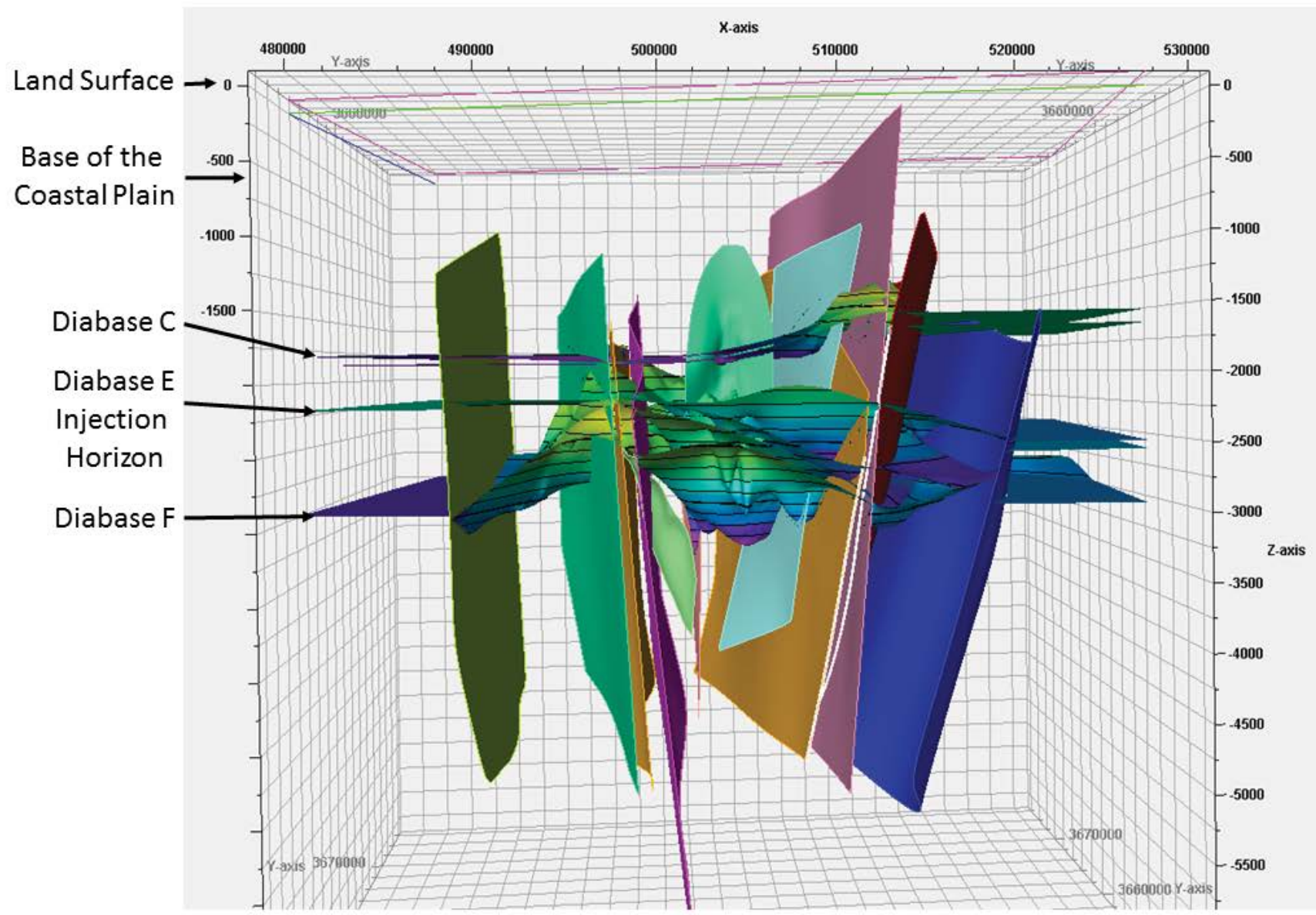

Figure 2: Petrel ${ }^{\mathrm{TM}}$ produced 3-D geologic model surfaces with the faults. This image illustrates the complexity of the geology and the amount of faulting in the study area. The various colors of each plane represent each individual fault. 
and base of diabase units $\mathrm{C}, \mathrm{E}$, and $\mathrm{F}$ (Figure 2). The results from the petrographic and core analyses ruled out using the sandstone as possible injection zones due to its aforementioned low porosity and permeability $(3.1 \%$ and $0.065 \mathrm{mD})$. The only possible porous zones that could be used for $\mathrm{CO}_{2}$ storage and injection simulation are along the diabase units. These diabase units are highly fractured and the Rizer \# 1 geophysical log indicates the average porosity to be approximately $10 \%$ and the average permeability to be approximately $10 \mathrm{mD}$. During the drilling of Rizer \# 1 , water flowed into the borehole from one of the diabase horizons and this empirically supports the log data that the diabase is highly fractured.

For phase two of the injection simulation modeling, two software packages were employed to build the injection simulation model Petrel $^{\mathrm{TM}}$ was used to construct a geo-cellular grid based on the 3-D geologic model. $\mathrm{CO}_{2}$ injection simulation was achieved using the compositional reservoir simulator CMG-GEM $[39,40]$. The geologic horizons were created in Petrel $^{\mathrm{TM}}$. These horizons were then imported into CMG-GEM as isopachs, thus maintaining the stratigraphic and structural boundaries of the geologic model.
The model volume used in all of the phase two simulations is 178 $\times 142 \times 50(\mathrm{x}, \mathrm{y}, \mathrm{z})$ for a total of $1,167,563$ active cells. The typical cell size is $100 \mathrm{~m} \times 100 \mathrm{~m} \times 200 \mathrm{~m}$. However, there was grid refinement of the injection horizon surrounding the injection well and $k$ values varied by the thickness of the horizon. Adjacent to the well, an area of 5 ( $\mathrm{x}$ direction $) \times 6$ (y direction) cells $(500 \mathrm{~m} \times 600 \mathrm{~m})$ was refined into $3(\mathrm{i}) \times 3(\mathrm{j}) \times 1(\mathrm{k})$ for a total of 2,700 refined cells for each layer in the model. Grid refinement is used to allow for the incorporation of greater spatial information in a computationally efficient way, thus creating a hierarchical concept of space around the injection well [7]. The $\mathrm{k}$ (vertical) cells varied in thickness along with the horizon surfaces were divided into 50 layers as follows (Figure 3, Table 1):

Layers 1 to 10: Diabase C

Layers 11 to 20: Sandstone 1

Layers 21 to 30: Diabase E

Layers 31 to 40: Sandstone 2

Layers 41 to 50: Diabase F

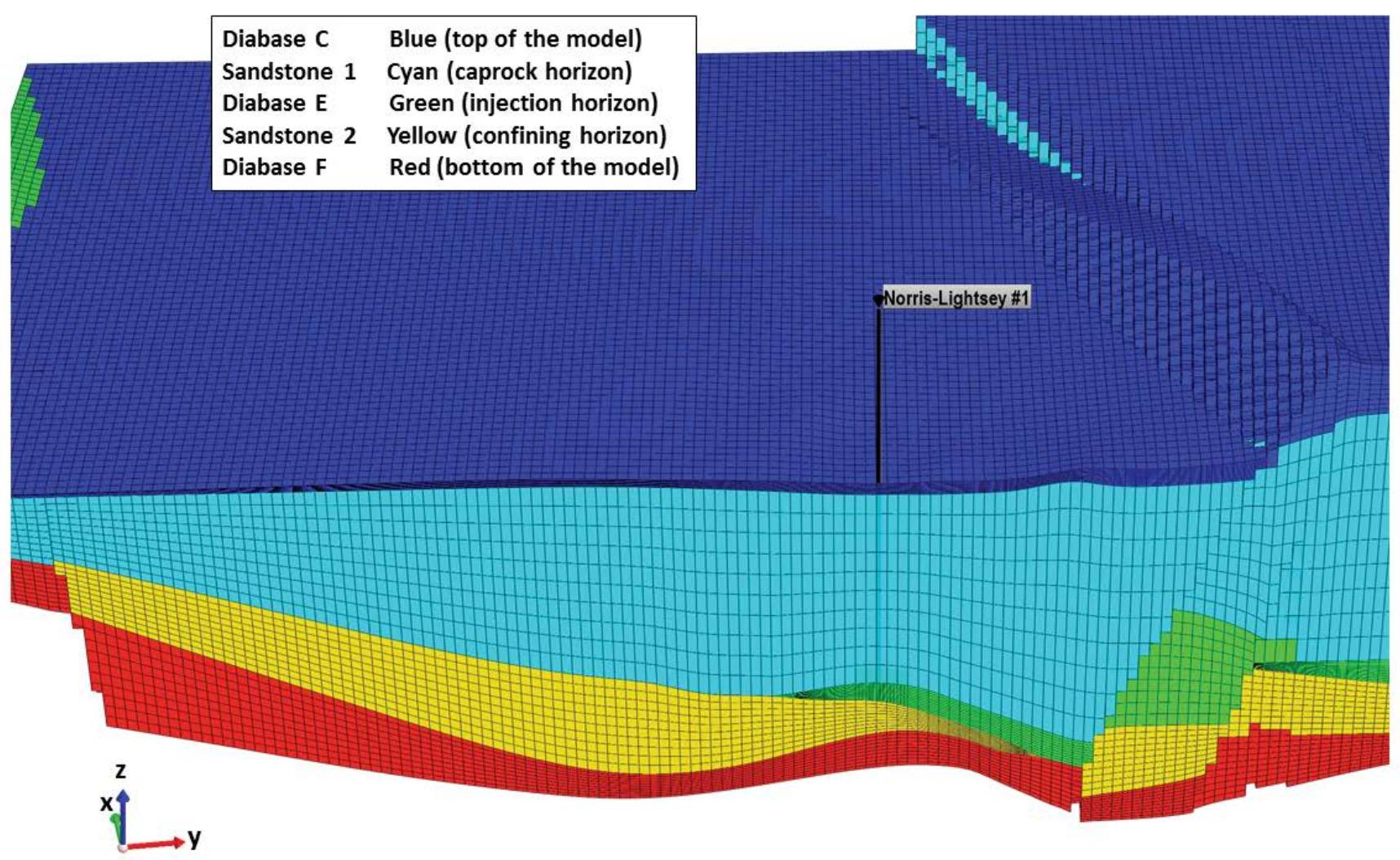

Figure 3: 3-D Cross section of the injection simulation model. This image shows the layers and complexity of the geology of the injection simulation model. The top of the model (blue) is Diabase $\mathrm{C}$ and is located beneath the Coastal Plain of South Carolina at a depth of $\sim 600 \mathrm{~m}$ below land surface. The bottom of the model (red) is Diabase $C$ and has a maximum depth of $\sim 3517 \mathrm{~m}$ below land surface.

Table 1: Injection simulation model domain information

\begin{tabular}{|c|c|c|c|c|c|}
\hline \multicolumn{6}{|c|}{ Injection Simulation Model Set Up } \\
\hline Material & 50 Layers Total in the Model & Depth (m) & Porosity (\%) & Permeability (mD) & Notes \\
\hline \multirow[t]{2}{*}{ Diabase C } & Surface Top Layer 1 & Minimum 1283 & \multirow[t]{2}{*}{10.0} & \multirow[t]{2}{*}{10} & \multirow[t]{2}{*}{ Top of the Model } \\
\hline & Surface Bottom Layer 10 & Maximum 1916 & & & \\
\hline \multirow[t]{2}{*}{ Sandstone 1} & Surface Top Layer 11 & Minimum 1387 & \multirow[t]{2}{*}{3.4} & \multirow[t]{2}{*}{0.065} & \multirow[t]{2}{*}{ Seal } \\
\hline & Surface Bottom Layer 20 & Maximum 2848 & & & \\
\hline \multirow[t]{2}{*}{ Diabase $\mathrm{E}$} & Surface Top Layer 21 & Minimum 1710 & \multirow[t]{2}{*}{10.0} & \multirow[t]{2}{*}{ 1-200 mD range } & \multirow[t]{2}{*}{ Injection Horizon } \\
\hline & Surface Bottom Layer 30 & Maximum 2953 & & & \\
\hline \multirow[t]{2}{*}{ Sandstone 2} & Surface Top Layer 31 & Minimum 1710 & \multirow[t]{2}{*}{3.4} & \multirow[t]{2}{*}{0.065} & \multirow[t]{2}{*}{ Seal } \\
\hline & Surface Bottom Layer 40 & Maximum 3453 & & & \\
\hline \multirow[t]{2}{*}{ Diabase F } & Surface Top Layer 41 & Minimum 1710 & \multirow[t]{2}{*}{10.0} & \multirow[t]{2}{*}{10} & \multirow[t]{2}{*}{ Base of the Model } \\
\hline & Surface Bottom Layer 50 & Maximum 3517 & & & \\
\hline
\end{tabular}

Citation: Brantley D, Waddell M, Shafer J, Lakshmi V (2016) Inclusion of Faults in 3-D Numerical Simulation of Carbon Dioxide Injection into the South Georgia Rift Basin, South Carolina. Int J Earth Sci Geophys 2:005 
In order to optimize the computation efficiency of the model, only the horizons below the coastal plain were used in the simulation modeling. These include Diabase C, Sandstone1, Diabase E, Sandstone 2 , and Diabase F. $\mathrm{CO}_{2}$ was injected into Diabase E and Sandstone 1 is assumed the caprock seal.

Material properties were assigned based on the Weatherford Laboratories results and the Rizer \# 1 petrophysical ELAN logs. All of the diabase horizons were assigned a porosity of $10 \%$ and a heterogeneous permeability distribution as shown in Figure 4. The permeability heterogeneity was generated by specifying a random permeability between 1 and $100 \mathrm{mD}$. The scale is logarithmic so the actual data is a random number between $>0$ and 2. This range was estimated based on the fractured nature of the diabase evidenced by the Rizer \# 1 petrophysical ELAN logs. All sedimentary horizons in the model serve as cap rock due to their low permeability and porosity. They are given a vertical and horizontal permeability of $0.065 \mathrm{mD}$ and porosity of $3.4 \%$. The simulation model parameters along with the horizon surfaces minimum and maximum depths are shown in Table 1. As with the preliminary model (phase one), 30 million tons of $\mathrm{CO}_{2}$ were injected at a rate of 1 million tons per year $\left(1.38 \mathrm{E} 7 \mathrm{~m}^{3}\right.$ per year) under reservoir pressure and temperature conditions, which is the DOE's stated minimum capacity to be considered a viable basin for geologic storage. Model complexity resulted in a significant amount of computer time to reach convergence. For this reason, we chose 100-year simulations for Phase two of the modeling. As with Phase one, the first 30 years were injection of supercritical $\mathrm{CO}_{2}$. However, instead of a 970 year shut-in as with phase one, there was only a 70-year shut-in with Phase two because of simulation time requirements. The first year of the simulation $(1 / 1 / 2014-12 / 31 / 2014)$ was used as time for model equilibration. Injection of supercritical $\mathrm{CO}_{2}$ started on 1/1/2015 and continued until year 2045 and shut-in spanned 2045 - 2115.The maximum time step was set to 30 days although this was rarely reached due to the complexity of the geology.

\section{$\mathrm{Co}_{2}$ Injection Results}

\section{Faults as seals - zero permeability}

To examine the impact of potential fault leakage, numerical simulations were conducted using a progressively higher permeability in the faults zones identified in the 3-D geologic model. For the first experiment, a permeability of $0 \mathrm{mD}$ was assigned to the faults. In this scenario, the faults serve as seals. As expected, the $\mathrm{CO}_{2}$ was contained in the injection zone Diabase $\mathrm{E}$ and there was no $\mathrm{CO}_{2}$ leakage or migration out of the target reservoir for the entire 100-year numerical experiment. Figure 5 is a 2-D image of the $\mathrm{CO}_{2}$ saturation of the top layer of Diabase E (layer 21 in the model) and shows the areal extent of the $\mathrm{CO}_{2}$ plume. Figure 6 plots the dissolved phase $\mathrm{CO}_{2}$ against the supercritical $\mathrm{CO}_{2}$. The $\mathrm{CO}_{2}$ is dissolving the fastest during the 30 -year injection phase and this slows as soon as the injection stops. However, $\mathrm{CO}_{2}$ continues to dissolve for the entire 100-year experiment - this is important because dissolution into the host brine is the third trapping mechanism of $\mathrm{CO}_{2}$ in geologic storage. This is corroborated by the supercritical $\mathrm{CO}_{2}$ plot peaking at the end of the injection period and then trending in a steady decline as more $\mathrm{CO}_{2}$ dissolves into the brine.

\section{Minor leaky fault - Low Permeability $1 \mathrm{mD}$}

For the second numerical experiment, a permeability of $1 \mathrm{mD}$ was assigned to the faults. This scenario represents a leaky fault with small interconnected fractures. This scenario is significant because alow permeability like $1 \mathrm{mD}$ may not be viewed as a significant source of leakage. Figure 7 shows the top of Diabase E (layer 21 of the model) and the 2-D areal extent of the $\mathrm{CO}_{2}$ plume migration at the top of the injection horizon. It closely resembles the plume extent in Figure 5. These plumes resemble each other in the 2-D view because the amount of leakage up the $1 \mathrm{mD}$ fault was $47 \%$ of the total volume of injected $\mathrm{CO}_{2}$ (Table 2), therefore $53 \%$ of the $\mathrm{CO}_{2}$ is trapped by the caprock and pooled in the top of the injection horizon. However as is shown in Figure 8 , even at permeability as low as $1 \mathrm{mD}$ causes significant leakage $(\sim 47 \%$ of the total injected $\mathrm{CO}_{2}$ ) and upward migration of $\mathrm{CO}_{2}$ out of the target reservoir. Figure 8 is a $3-\mathrm{D}$ image of the $\mathrm{CO}_{2}$ migration over the 100 -year

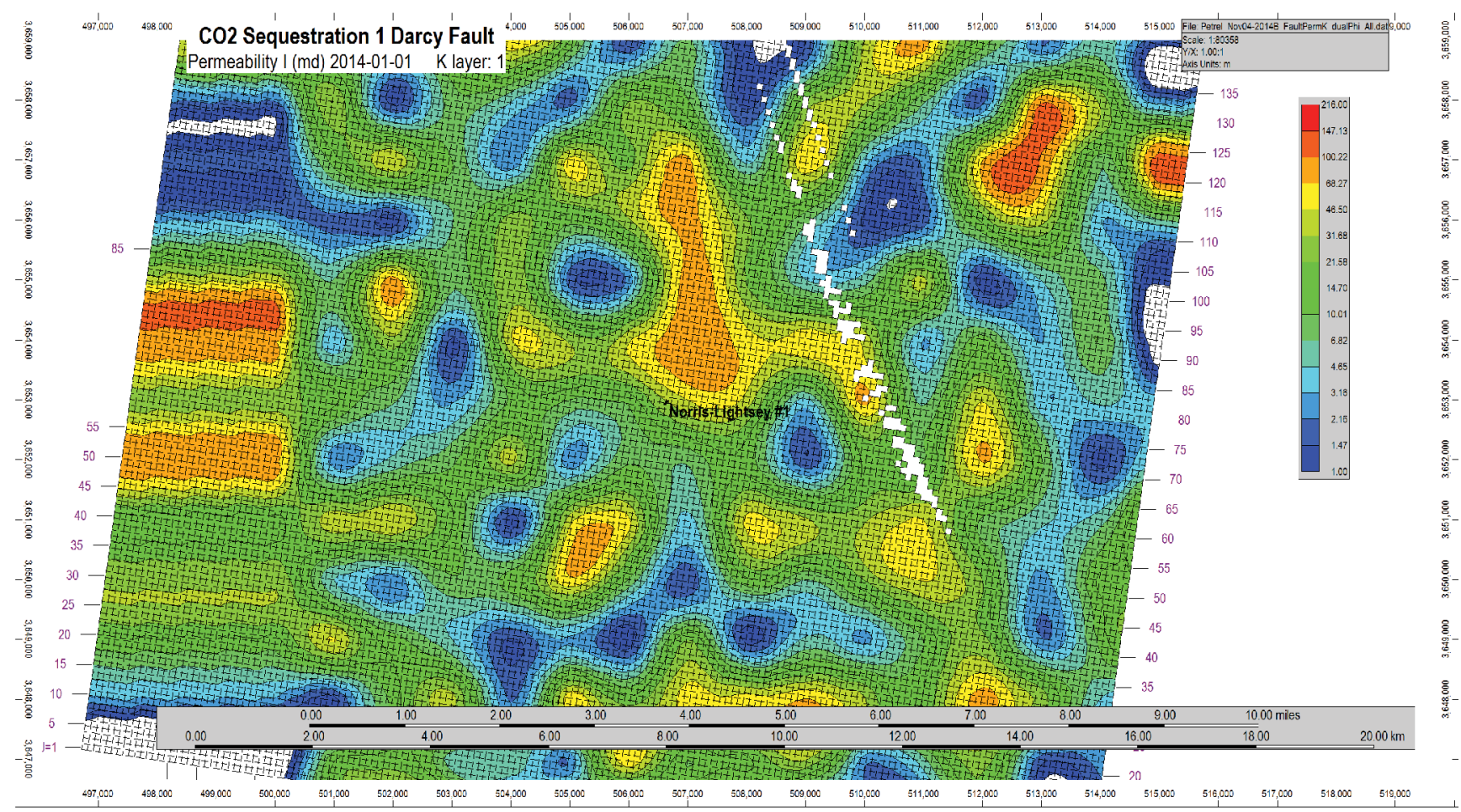

Figure 4: Layer 1 (top of the model) permeability distribution. This distribution was used for all of the Diabase layers and ranges in value between 1 and 200 $\mathrm{mD}$. The left side of the permeability map is stretched as a results of the final simulation model grid extending slightly further than the permeability map that was exported from Petrel ${ }^{\mathrm{TM}}$. The white diagonal feature is a fault that extends through the top of the model. 
South Georgia Rift Basin

Gas Saturation 2115-01-01 K layer: 21

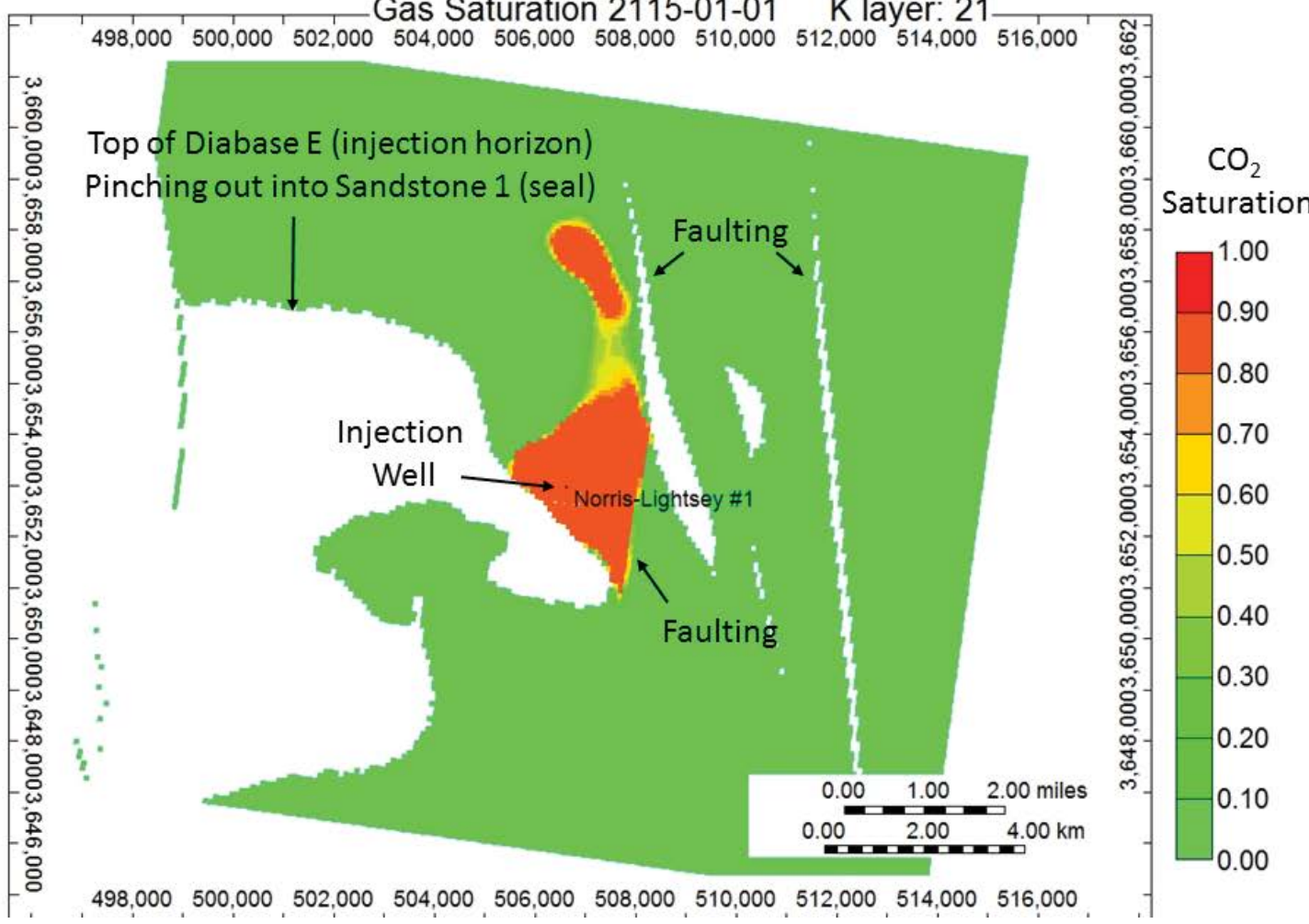

Figure 5: 2-D image of $\mathrm{CO} 2$ saturation of the top layer of Diabase $\mathrm{E}$ showing the areal extent of the $\mathrm{CO}_{2}$ plume as a result of 30 millions tons of $\mathrm{CO} 2$ injected for 30 years with a 70 year shut-in. In this experiment, the faults permeability was $0 \mathrm{mD}$ and all of the injected $\mathrm{CO}_{2}$ remained in the target reservoir, Diabase $\mathrm{E}$. This image displays the more buoyant $\mathrm{CO}_{2}$ rising up the top surface Diabase $\mathrm{E}$ and being laterally sealed by the fault and horizontally sealed by Sandstone 1 .

Dissolved Phase $\mathrm{CO} 2$ vs Supercritical $\mathrm{CO} 2$

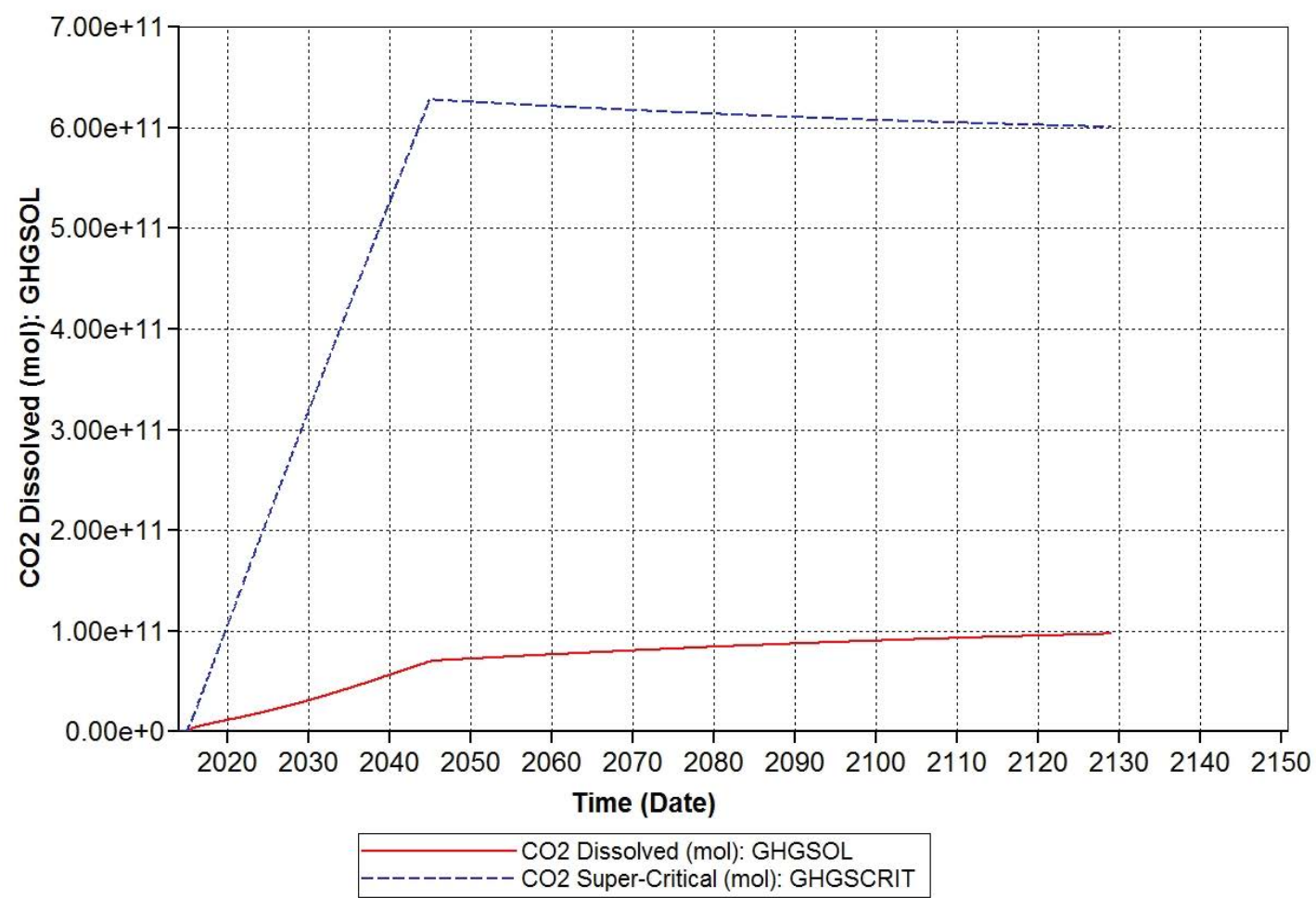

Figure 6: Plot of dissolved phase $\mathrm{CO}_{2}$ vs supercricitical $\mathrm{CO}_{2}$. In this experiment, the faults permeability was $0 \mathrm{mD}$ and all of the injected $\mathrm{CO}_{2}$ remained in Diabase $\mathrm{E}$. The injection stopped and shut-in started $1 / 1 / 2045$. Solubility is a trapping mechanism that begins with injection and can continue until the all of the mechanically or chemically untrapped $\mathrm{CO}_{2}$ is in solution. 
simulation. As can be seen in Figure 8, the $\mathrm{CO}_{2}$ migrates up the faults and pools in Diabase C, which is the top boundary of the model. Given the injection depth of $[(\sim 1710 \mathrm{~m}-2953 \mathrm{~m} ; 5610 \mathrm{ft}$. - $9688 \mathrm{ft}$. (Table 1)] and the 100 year time scale, the $\mathrm{CO}_{2}$ transport is mainly due to buoyancy and dispersion, not advection. The injected $\mathrm{CO}_{2}$ has a specific gravity at the injection depth of approximately 0.7 [41]. Therefore, due to buoyancy, the $\mathrm{CO}_{2}$ will rise in the more dense brine occupying the pore space. This can be seen in Figure 8 as the $\mathrm{CO}_{2}$ follows the contours up dip in the formation and pools up against the bottom of the cap rock as well as traveling up the permeable faults and pooling at the top boundary of the model.

\section{Leaky fault - Permeability of $100 \mathrm{mD}$}

For the final numerical experiment, a permeability of $100 \mathrm{mD}$ was assigned to the faults. This experiment represents a highly fractured fault zone with a high leakage rate. Figure 9 is a 2-D image of the areal extent of the plume at the top of the model in Diabase $\mathrm{C}$. This image shows that much of the $\mathrm{CO}_{2}$ has migrated up the fault and pooling in high concentrations in the top layer of the model. Figure 10 is a $3-\mathrm{D}$ image of $\mathrm{CO}_{2}$ saturation after 100 year simulation with the fault permeability set to $100 \mathrm{mD}$. This image better displays the amount of $\mathrm{CO}_{2}$ that has traveled up the fault out of the target reservoir of Diabase E and into Diabase C. This is significant because it illustrates that a fault with $100 \mathrm{mD}$ permeability is a large conduit and $\mathrm{CO}_{2}$ will escape at a very rapid rate on a human time scale. In the 100 year simulation, $~ 85 \%$ of the $\mathrm{CO}_{2}$ injected migrated up to the top of the model (Table 2, Figure 11).

It was determined that at injection depth, the lithostatic pressure ranges from $\sim 60$ - $65 \mathrm{MPa}$. The maximum injection pressure is $\sim 31$ $\mathrm{MPa}$, which is approximately half of the lithostatic pressure in the injection zone (Figure 12) thus indicating injecting activity would not induce seismicity and further fracturing.

\section{Discussion and conclusion}

The results of this study show the importance of:

1) Inclusion of accurate geologic structure (particularly faults) into $\mathrm{CO}_{2}$ injection simulation modeling,

2) Knowledge of whether the faults act as leaky conduits or seals,

3) Accurate fault permeability data for the containment of $\mathrm{CO}_{2}$ and

4) Having correct reservoir data, in particular porosity and permeability for injection simulation modeling.

The results from this research illustrate that even with a permeability of $1 \mathrm{mD}$ significant leakage and migration of $\mathrm{CO}_{2}$ occurs up faults (Table 2). Figure 12 graphically compares the volume $\left(\mathrm{m}^{3}\right)$ of $\mathrm{CO}_{2}$ that remained in the target reservoir with the fault permeability set to $1 \mathrm{mD}$ and $100 \mathrm{mD}$. This graph makes it easier to visualize, conceptualize and compare the amount of $\mathrm{CO}_{2}$ that was injected versus the amount of $\mathrm{CO}_{2}$ that remained in the target reservoir. This is evidence that fault analysis can be a critical factor in injection

Table 2: $\mathrm{CO}_{2}$ volume injected vs leakage analysis for $1 \mathrm{mD}$ and $100 \mathrm{mD}$ faults.

\begin{tabular}{|l|l|l|}
\hline Fault Permeability & \multicolumn{1}{|c|}{$\mathbf{1 ~ m D}$} & \multicolumn{1}{c|}{$100 \mathrm{mD}$} \\
\hline Total $\mathrm{CO}_{2}$ Injected $\left(\mathrm{m}^{3}\right)$ & $1.6432 \mathrm{E}+10$ & $1.6432 \mathrm{E}+10$ \\
\hline Simulation Time (years) & 100 & 100 \\
\hline $\mathrm{CO}_{2}$ Remaining in Diabase $\mathrm{E}\left(\mathrm{m}^{3}\right)$ & $7.0634 \mathrm{E}+09$ & $2.4183 \mathrm{E}+09$ \\
\hline $\mathrm{CO}_{2}$ Leakage in Diabase $\mathrm{E}\left(\mathrm{m}^{3}\right)$ & $9.3682 \mathrm{E}+09$ & $1.4013 \mathrm{E}+10$ \\
\hline Percent of $\mathrm{CO}_{2}$ Remaining in Diabase E & $57.01 \%$ & $14.72 \%$ \\
\hline Percent of $\mathrm{CO}_{2}$ Leakage out of Diabase $\mathrm{E}$ & $42.99 \%$ & $85.28 \%$ \\
\hline Leakage Rate $\left(\mathrm{m}^{3} /\right.$ day) & $1.2898 \mathrm{E}+05$ & $1.9293 \mathrm{E}+05$ \\
\hline Leakage Rate $\left(\mathrm{m}^{3} /\right.$ year $)$ & $7.8857 \mathrm{E}+06$ & $1.1796 \mathrm{E}+07$ \\
\hline Injection Rate $\left(\mathrm{m}^{3} /\right.$ day $)$ & $2.2622 \mathrm{E}+05$ & $2.2622 \mathrm{E}+05$ \\
\hline Injection Rate $\left(\mathrm{m}^{3} /\right.$ year $)$ & $1.3831 \mathrm{E}+07$ & $1.3831 \mathrm{E}+07$ \\
\hline
\end{tabular}

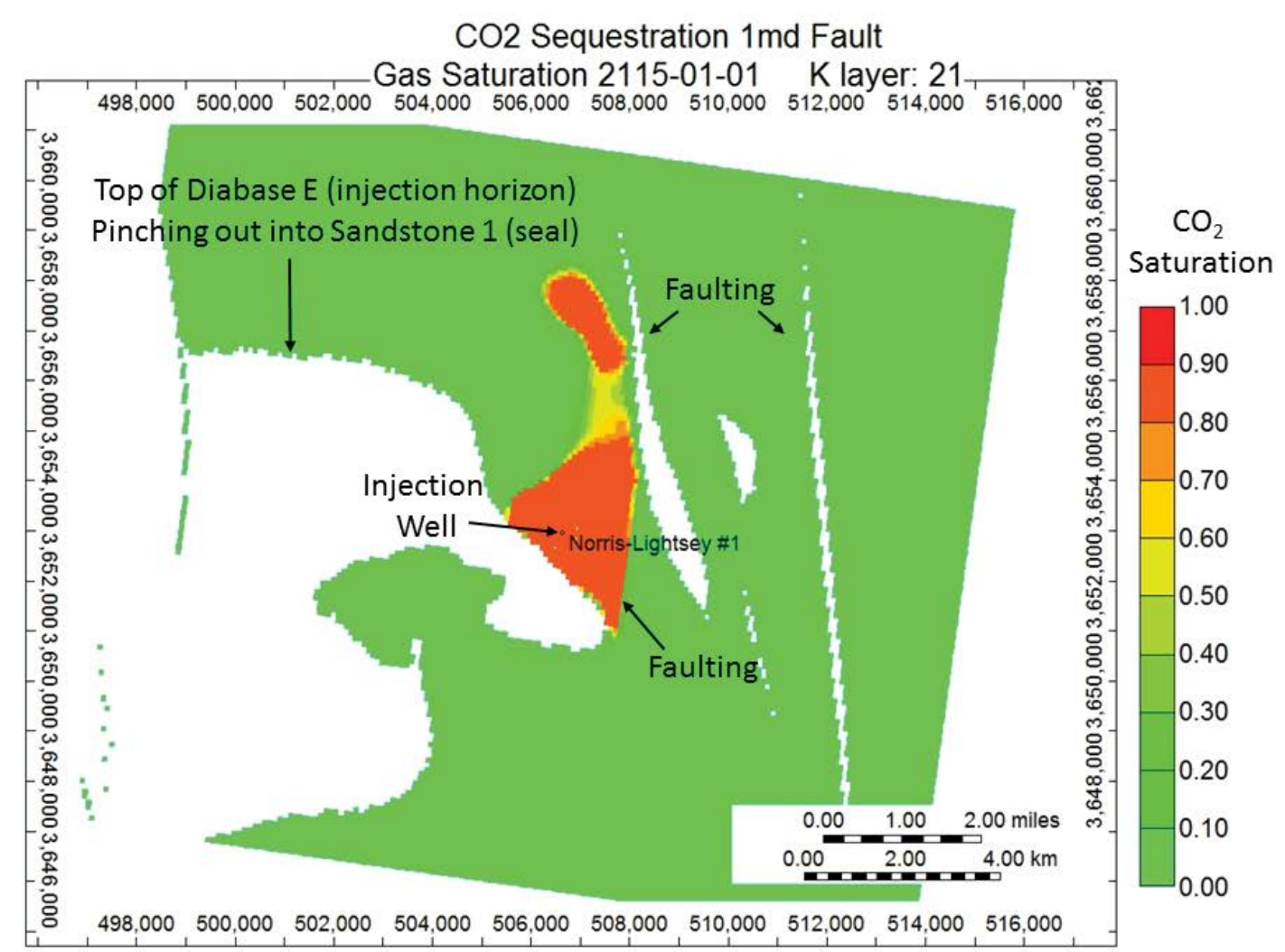

Figure 7: 2-D image of the $\mathrm{CO}_{2}$ saturation of the top layer of Diabase $\mathrm{E}$ (layer 21) showing the areal extent of the $\mathrm{CO}_{2}$ plume as a result of 30 millions tons of $\mathrm{CO}_{2}$ injected for 30 years with a 70 year shut-in with a fault permeability of $1 \mathrm{mD}$. Leakage out of the target reservoir has happened but it is hard to see in 2-D surface view. 


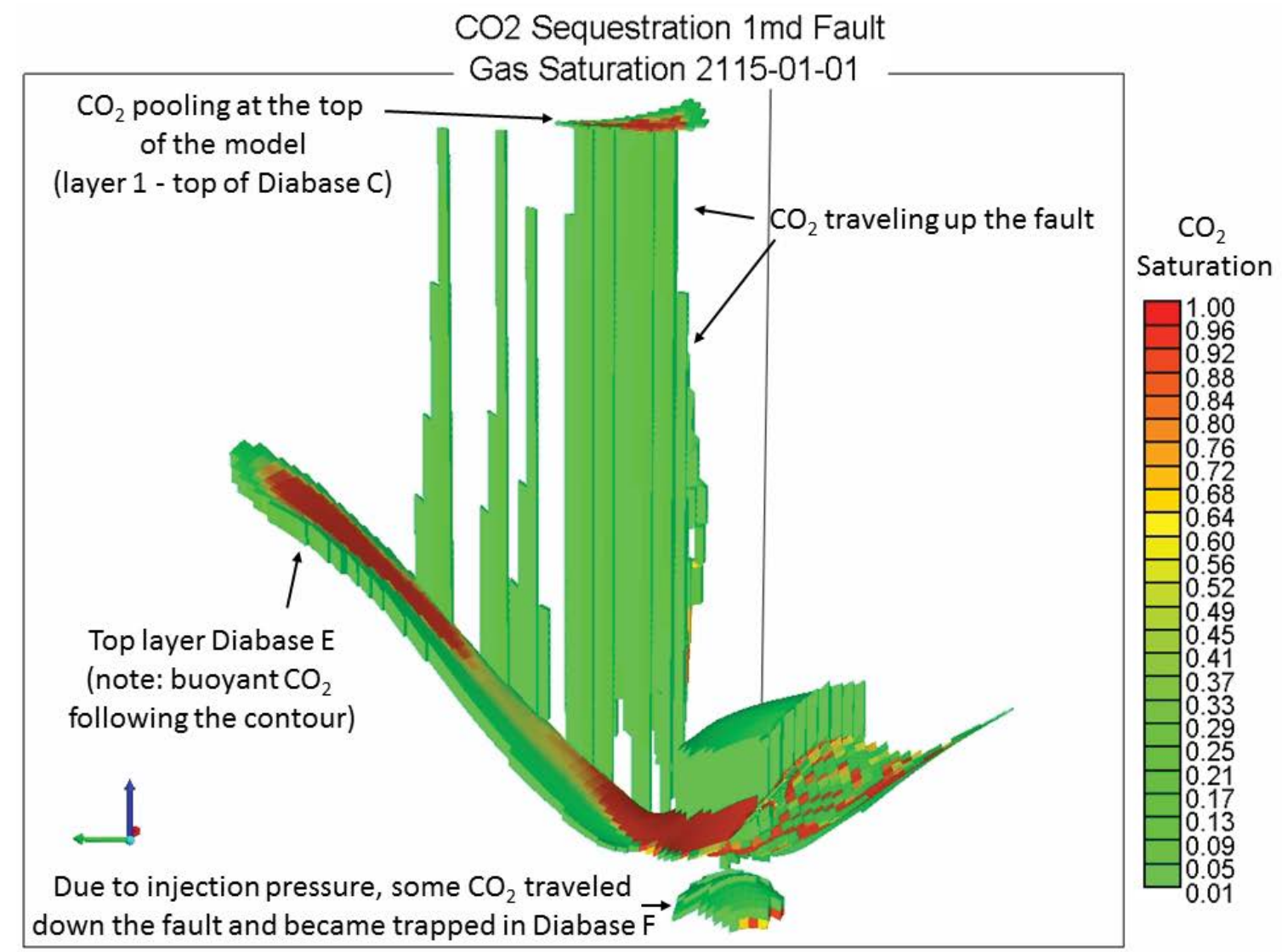

Figure 8: 3-D image of $\mathrm{CO}_{2}$ saturation after 100 year simulation with the fault permeability set to $1 \mathrm{mD}$. This 3-D image illustrates that: 1) Even with a permeability of $1 \mathrm{mD}$, there is significant leakeage out of the target reservoir up the faults into Diabase C, which is the top of horizon of the model and 2) The complexity of the geology. Note the topography of the Diabase C surface.

CO2 Sequestration $100 \mathrm{mD}$ Fault

Gas Saturation 2115-01-01 K layer: 1
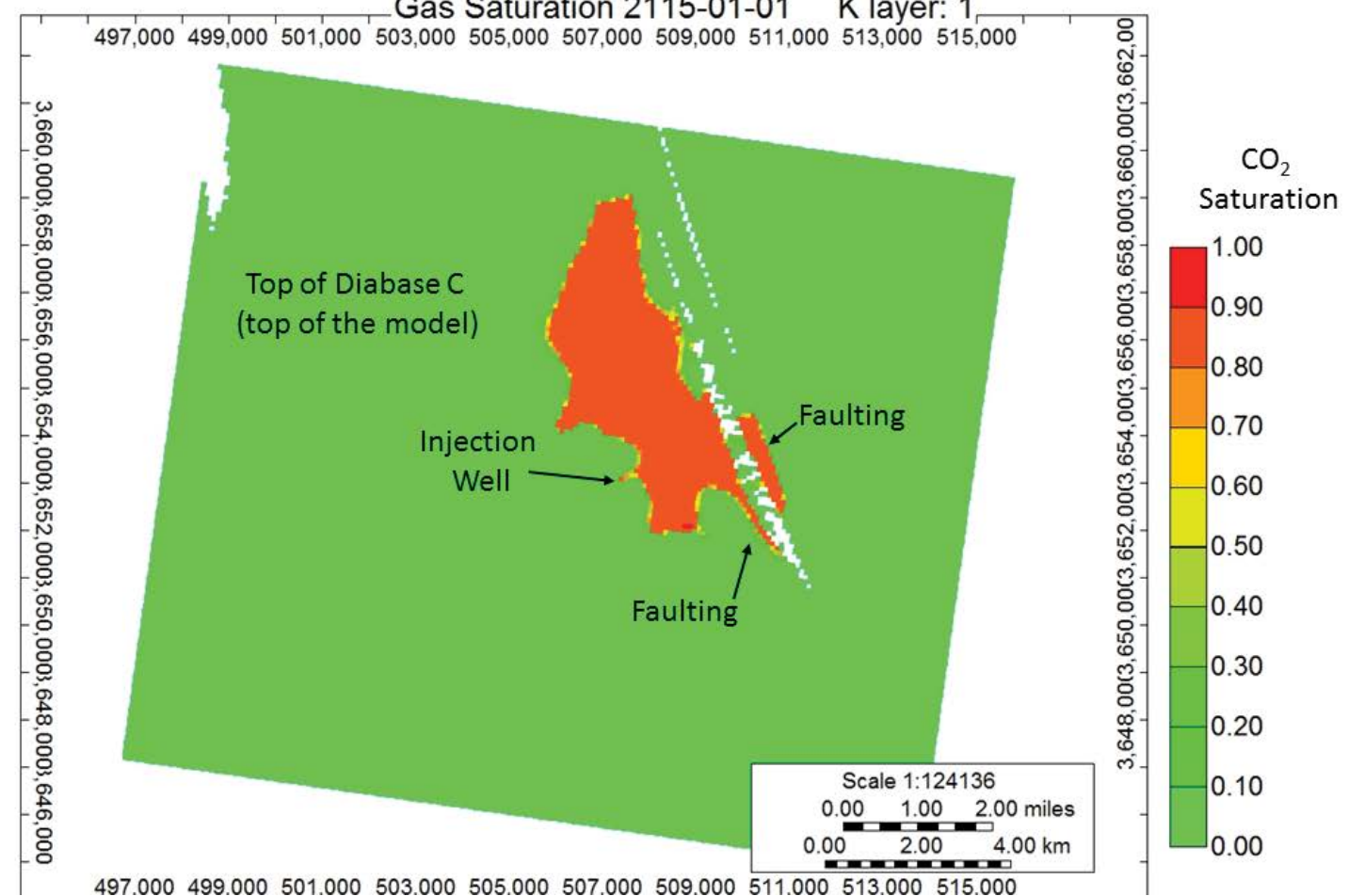

497.000499 .000501 .000503 .000505 .000507 .000509 .000511 .000513 .000515 .000

Figure 9: Surface image of the $\mathrm{CO}_{2}$ saturation of the top layer of Diabase $\mathrm{C}$ (layer 1 ) showing the areal extent of the $\mathrm{CO}_{2}$ plume as a result of 30 millions tons of $\mathrm{CO}_{2}$ injected for 30 years with a 70 year shut-in with a fault permeability of $100 \mathrm{mD}$. A large portion of the $\mathrm{CO}_{2}$ has migrated up through the faults into Diabase $\mathrm{C}$, which is the top of the model, and pooled in high concentration. 


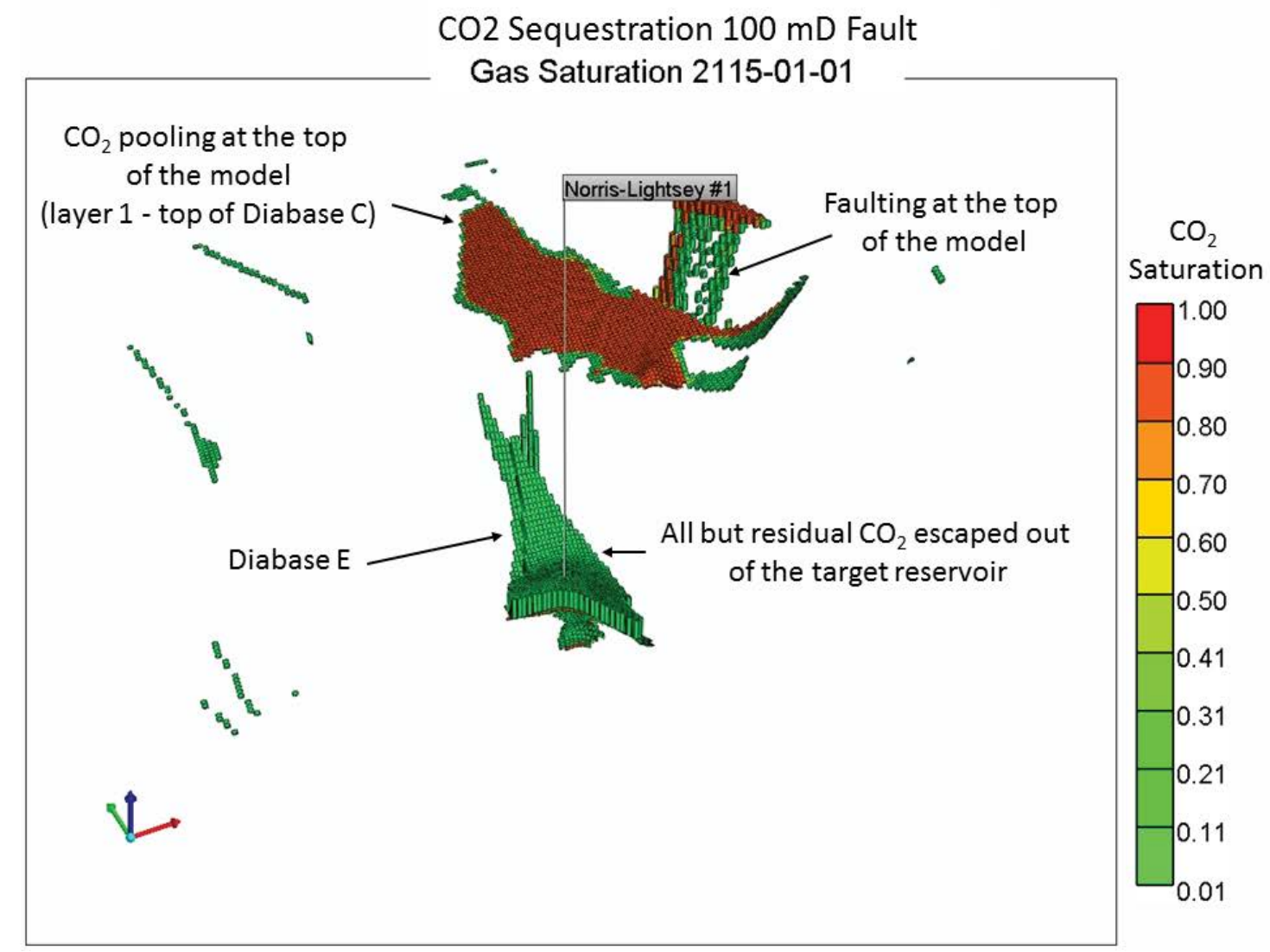

Figure 10: 3-D image of $\mathrm{CO}_{2}$ saturation after 100 year simulation with the fault permeability set to $100 \mathrm{mD}$. This 3-D image displays (1) significant leakeage up the faults into Diabase $\mathrm{C}$, which is the top of horizon of the model, and (2) the complexity of the geology. In the 100 year simulation, most of the $\mathrm{CO}_{2}$ injected migrated up to the top of the model pooling in high concentrations.

Total injected vs. remaining $\mathrm{CO}_{2}\left(\mathrm{~m}^{3}\right)$ in Diabase $\mathrm{E}$ (target reservoir) after 100 year simulation

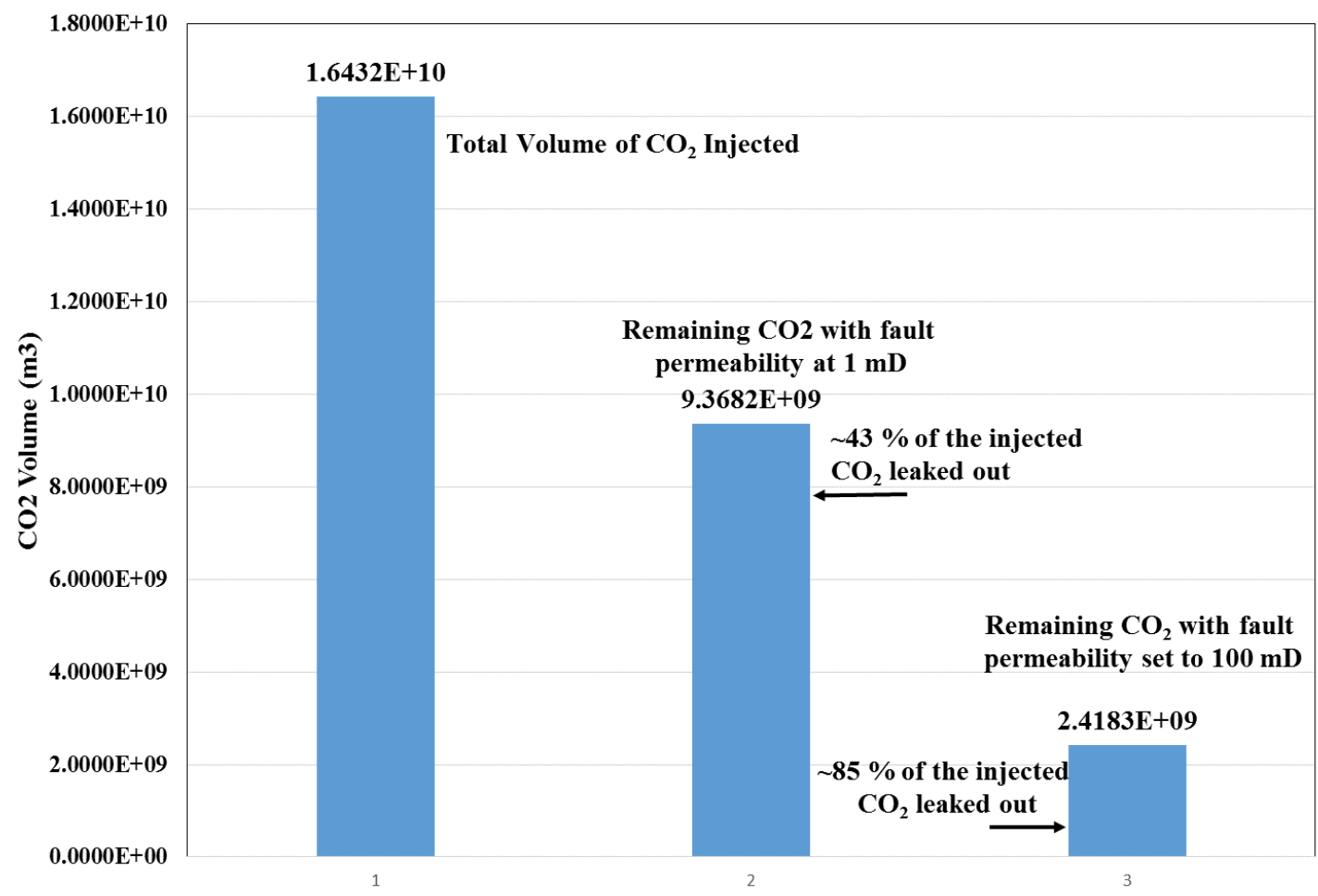

Figure 11: Graph of the $\mathrm{CO}_{2}$ remaining in Diabase $\mathrm{E}$ (target reservoir) after the 100 year simulation. The difference between the remaining and total injected is the amount of $\mathrm{CO}_{2}$ leakage. 


\section{Simulation results: pressure response ( $0 \mathrm{mD}$ faults)}

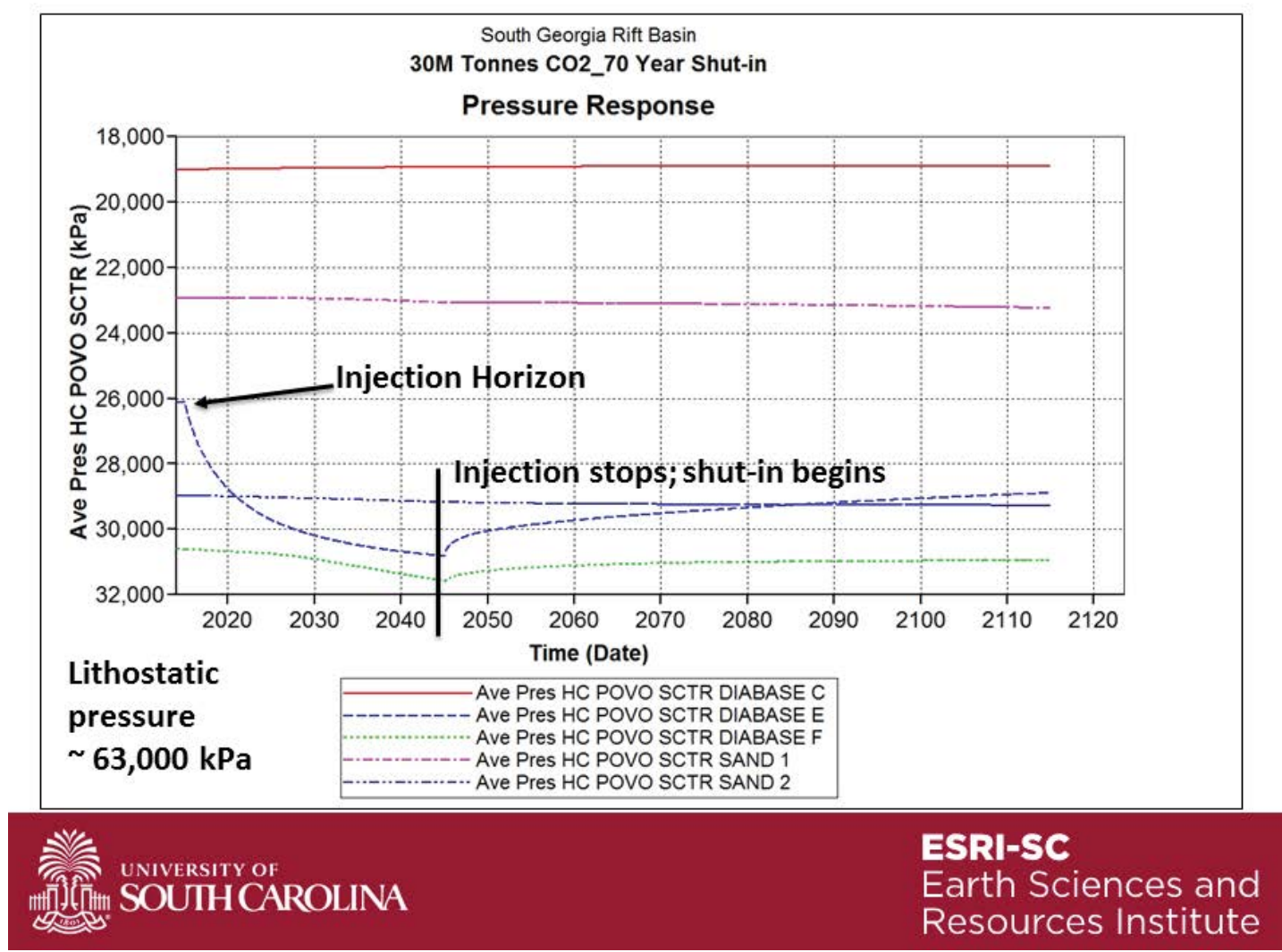

Figure 12: Plot of the basin pressure response of each horizon at the injection well. Diabase $E$ (blue dashed line), the injection horizon, has the largest response. Most of the pressure was contained by the Sandstone seal (pink line) above the target reservoir. In this experiment, the faults permeability was 0 and all of the injected $\mathrm{CO}_{2}$ remained in Diabase E. Note that the maximim injected pressure is below half of the reservoir lithostatic pressure ( 63 MPa). HC POVO SCTR is the CMG-GEM software terminology for hydrocarbon pore volume pressure in a particular sector, or in this case $\mathrm{CO}_{2}$ pore volume pressure in a particular horizon.

simulation modeling and ultimately in evaluating the efficacy and risk of long term geologic storage of $\mathrm{CO}_{2}$ and that even low permeability faults make the geology potentially unsuitable.

The results from Phase 1 of the injection simulation modeling [7] suggested the SGR basin was suitable for long term geologic storage of $\mathrm{CO}_{2}$. However, the results from the more detailed phase two modeling shows the suitability of the SGR basin for long term storage of $\mathrm{CO}_{2}$ remains inconclusive due to lack accurate data on the fault properties and juxtaposition, given the influence faults may have on $\mathrm{CO}_{2}$ migration. If the faults act as seals, this portion of the SGR basin is suitable for $\mathrm{CO}_{2}$ injection using the highly fractured diabase layers as the reservoir horizons and the low porosity and permeability sedimentary sandstone layers as the seals. However, if the faults have as little as $1 \mathrm{mD}$ of permeability, the seal is compromised and $\mathrm{CO}_{2}$ will migrate upwards out of the intended reservoir at a rate of 7.8857E + $06 \mathrm{~m}^{3}$ per year, thus deeming this portion of the SGR basin unsuitable for long term geologic storage of $\mathrm{CO}_{2}$. It should be noted that the SGR basin is composed of numerous sub-basins and this study only looked at portions of one sub-basin.

In summary, in the South Carolina (SC) portion of the SGR basin, 30 million tons of $\mathrm{CO}_{2}$ can be injected into the diabase units if the fracture network is continuous through the units, however, due to the severity of the faulting there is no way of assuring the injected $\mathrm{CO}_{2}$ will not migrate upward into the overlying Coastal Plain aquifers. In SC, the seismic data suggest the faulting extends upward into the Coastal Plain making that area not suitable for $\mathrm{CO}_{2}$ storage. The complex faulting observed at the study areas appear to be associated with transfer fault zones [34]. Newly acquired seismic data in the Georgia portion of the SGR basin suggest there are porous zones in the $J / T_{R}$ sandstones that could be used for geologic storage of $\mathrm{CO}_{2}$ here. These porous zones will need to be far away from the transfer fault zones identified by Hefner [34] to ensure containment of injected $\mathrm{CO}_{2}$. It also needs to be stressed that the SGR basin covers area in four states (South Carolina, Georgia, Alabama and Florida). The injection simulations conducted in this study were limited to one small area. Consequently, there is enormous potential for $\mathrm{CO}_{2}$ storage in other portions the basin and further research needs to be done to locate these suitable areas.

\section{Acknowledgements}

I would like to thank the United States Department of Energy for sponsoring this study through the National Energy and Technology Laboratory's "Site Characterization of Promising Geologic Formations of $\mathrm{CO}_{2}$ Storage" grant DE-FE0001965. I would also like to thank my dissertation committee, Dr. Camelia Knapp, Dr. John Shafer, Dr. Venkat Lakshmi and Dr. Jim Kellogg. Their guidance and encouragement was a critical and necessary component of this paper being completed. I would also like to thank the Computer Modeling Group, in particular, Dr. Jim Erdle for graciously discounting the GEM compositional simulator to the University of South Carolina. I would also like to thank Gene Williams of Williams Consulting for his expertise and guidance on $\mathrm{CO}_{2}$ injection simulation and specifically with his expertise using CMG-GEM software package.

\section{References}

1. Bachu S (2000) Sequestration of $\mathrm{CO} 2$ in geological media in response to climate change: road map for site selection using the transform of geological space into the $\mathrm{CO} 2$ phase space. Energy Conversion and Management 43: 87-102. 
2. Goldberg DS, Takahashi T, Slagle AL (2008) Carbon dioxide sequestration in deep-sea basalt. Proc Natl Acad Sci U S A 105: 9920-9925.

3. Zoback MD, Gorelick SM (2012) Earthquake triggering and large-scale geologic storage of carbon dioxide. Proc Natl Acad Sci U S A 109: 10164-10168.

4. Pires JCM, Martins FG, Alvim-Ferraz MCM, Simoes M (2011) Recent developments on carbon capture and storage: An overview. Chemical Engineering Research and Design 89: 1446-1460.

5. Dai Z, Keating E, Bacon D, Viswanathan H, Stauffer P, et al. (2014) Probabilistic evaluation of shallow groundwater resources at a hypothetical carbon sequestration site. Scientific Reports 4: 4006.

6. Bacon D, Qafoku N, Dai Z, Keating E, Brown C (2015) Modeling the Impact of Carbon Dioxide Leakage into an Unconfined, Oxidizing Carbonate Aquifer Int J of Greenhouse Gas Control 44: 290-299.

7. Brantley DT, Shafer JM, Lakshmi V (2015) $\mathrm{CO}_{2}$ Injection Simulation into the South Georgia Rift Basin for Geologic Storage. Environmental Geosciences (in press).

8. Nasvi MCM, Ranjith PG, Sanjayan J, Hague A (2013) Sub- and supercritical carbon dioxide permeability of wellbore materials under geological sequestration conditions: An experimental study. Energy 54: 231-239.

9. Leung DCY, Caramanna G, Maroto-Valer MM (2014) An overview of curren status of carbon dioxide capture and storage technologies. Renewable and Sustainable Energy Reviews 39: 426-443.

10. Cinar Y, Riaz A (2014) Carbon dioxide sequestration in saline formations: Part 2-Review of multiphase flow modeling. Journal of Petroleum Science and Engineering 124: 381-398.

11. Dai Z, Middleton R, Viswanathan H, Fessenden-Rahn J, Bauman J, et al. (2014) An integrated framework for optimizing $\mathrm{CO} 2$ sequestration and enhanced oil recovery, Environmental Science \& Technology Letters 1: 49-54.

12. Riaz A, Cinar $Y$ (2014) Carbon dioxide sequestration in saline formations: Part 1-Review of the modeling of solubility trapping. Journal of Petroleum Science and Engineering 124: 367-380.

13. Park Y, Kim DY, Lee JW, Huh DG, Park KP, et al. (2006) Sequestering carbon dioxide into complex structures of naturally occurring gas hydrates. Proc Natl Acad Sci U S A 103: 12690-12694.

14. Akintunde OM, Knapp C, Knapp JH (2013) Petrophysical characterization of the South Georgia Rift Basin for supercritical $\mathrm{CO}_{2}$ storage: a preliminary assessment. Environmental Earth Science 70: 2971-2985.

15. Heffner DM, Knapp JH, Akintunde OM, Knapp CC (2011) Preserved extent of Jurassic flood basalt in the South Georgia Rift: A new interpretation of the horizon. Geology 40: 167-170.

16. Shafer JM, Brantley DT (2011) Characterizing a Geologic Formation. Chemical Engineering Progress 50-52.

17. Nelson PH, Kibler, JE (2003) A Catalog of Porosity and Permeability from Core Plugs in Siliciclastic Rocks. USGS, open file report 03-420: Denver, Colorado, Department of the Interior.

18. United States Department of Energy (2006) Carbon Sequestration Atlas of the United States and Canada. Appendix A - Methodology for Development of Carbon Sequestration Capacity Estimates. National Energy and Technology Laboratory.

19. Schlumberger (2015) Petrel ${ }^{\mathrm{TM}}$ E\&P Software Platform. Accessed Novembe 2014.

20. Rutqvist J, Birkholzer J, Cappa F, Tsang CF (2007) Estimating maximum sustainable injection pressure during geological sequestration of $\mathrm{CO}_{2}$ using coupled fluid flow and geomechanical fault-slip analysis. Energy Conversion and Management 48: 1798-1807.

21. Deng H, Stauffer PH, Dai Z, Jiao Z, Surdam RC (2012) Simulation of industrial-scale $\mathrm{CO}_{2}$ storage: multi-scale heterogeneity and its impacts on storage capacity, injectivity and leakage. International Journal of Greenhouse Gas Control 10: 397-418.

22. Pruess K (2005) ECO2: A TOUGH2 Fluid Property Module for Mixtures of Water, $\mathrm{NaCl}$, and $\mathrm{CO} 2$. University of California, Berkeley, CA 64720 Lawrence Berkeley National Laboratory - Earth Sciences Division.

23. Hou ZM, Gou Y, Taron J, Gorke UJ, Kolditz O (2012) Thermo-hydromechanical modeling of carbon dioxide injection for enhanced gas-recovery (CO2-EGR): a benchmarking study for code comparison. Environmental Earth Science 67: 549-561.

24. Zang K, Moridis G, Pruess K (2011) TOUGH+CO2: A multiphase fluid flow simulation for $\mathrm{CO} 2$ geologic storage sequestration in saline aquifers. Computers and Geosciences 37: 714-723.

25. Omambia AN, Li Y (2010) Numeric modeling of carbon dioxide sequestration in deep saline aquifers in Wangchang Oilfield-Jianghan Basin, China. Journal of American Science 6: 178-187.
26. Basburg B, Gumrah F (2005) Simulating the effects of deep saline aquifer properties on $\mathrm{CO} 2$ sequestration. $6^{\text {th }}$ Canadian International Petroleum Conference, Calgary Canada.

27. Frangeul J, Nghiem L, Caroli E, Thibeau S (2004) Sleipner/Utsira CO2 geological storage: full field flow and geochemical coupling to assess the long term fate of the CO2. Proceedings AAPG Annual Conference, Paper AAPG.

28. Shu L, Ruina X, Peixue J (2012) Effect of reactive surface area of minerals on mineralization trapping of $\mathrm{CO} 2$ in saline aquifers. Petroleum Science 9: 400-407.

29. Thibeau S, Nghiem $L$ (2007) A modeling study of the role of selected minerals in enhancing $\mathrm{CO} 2$ mineralization during $\mathrm{CO} 2$ aquifer storage. SPE Annual Technical Conference and Exhibition, Anaheim, USA.

30. Akintunde OM, Knapp C, Knapp JH, Heffner DM (2013) New constraints on buried Triassic basins and regional implication for subsurface $\mathrm{CO}_{2}$ storage from the SeisData6 seismic profile across the Southeast Georgia coastal plain. Environmental Geosciences 20: 17-29.

31. Dai Z, Stauffer PH, Carey JW, Middleton RS, Lu Z, et al. (2014) Pre-site characterization risk analysis for commercial-scale carbon sequestration. Environmental Science \& Technology 48: 3908-3915

32. Clendenin CW, Waddell MG, Addison AD (2011) Reactivation and overprinting of the South Georgia Rift Extension. Geological Society of AmericaAnnual Meeting Abstracts with Program 43: 551

33. Clendenin CW (2013) Insights into mode of the South Carolina rift extension in eastern Georgia, USA. Tectonophysics 608: 613-621.

34. Heffner DM (2013) Tectonics of the South Georgia Rift. University of South Carolina, Columbia, SAC 29208.

35. Hollon B, Mainali P, Dix M, Fu R, Houghton N et al. (2014) Whole Rock Bulk Geochemistry in Evaluating a $\mathrm{CO}_{2}$ Injection Well. Proceedings from the AAPG Annual Convention and Exhibit 2014, Houston, TX.

36. Rine JM, Hollon B, Fu R, Houghton N, Waddell M (2014) Diagenetic and Burial History of a Portion of the Late Triassic South Georgia Rift Basin Based on Petrologic and Isotopic (018) Analyses of Sandstones from Test Borehole Rizer \#1, Colleton County, SC. Proceedings from the AAPG Annual Convention and Exhibit 2014, Houston, TX.

37. Waddell MG, Addison AD, Brantley D, Knapp C (2011) Reservoir and caprock assessment using existing seismic and well data for $\mathrm{CO}_{2}$ geologic sequestration in the South Georgia Rift basins of the lower Coastal Plain of SC. AAPG Annual Conference and Exhibition, Houston TX.

38. Waddell MG, Brantley D Addison AD (2014) Characterization of the South Georgia Rift Basin for Source Proximal $\mathrm{CO}_{2}$ Storage. Final Technical Report, South Carolina Research Foundation, 1600 Hampton Street, Columbia, SC 29208

39. Delshad M, Wheeler MF, Kong X (2010) A Critical Assessment of CO Injection Strategies in Saline Aquifers. Society of Petroleum Engineers Western Regional Meeting 1: 205-222.

40. Saadatpoor E, Bryant SL, Sepehrnoori K (2009) New Trapping Mechanism in Carbon Sequestration. Transp Porous Med 83: 3-17.

41. Mammoli AA, Brebbia CA (2011) Computational Methods in Multiphase Flow VI. WIT Transactions on Engineering Sciences 70: 312. 